\title{
PENDIDIKAN SPIRITUAL BERBASIS TAREKAT BAGI PECANDU NARKOBA \\ (Studi Kasus di Pondok Pesantren As-Stressiyah Darul Ubudiyah Sejati Sejomulyo Juwana Pati)
}

\author{
Fathur Rohman \\ (Universitas Islam Nahdlatul Ulama Jepara)
}

\begin{abstract}
Abstrak:
Tulisan ini bermaksud untuk memberikan gambaran tentang pelaksanaan pendidikan spiritual berbasis tarekat bagi pecandu narkoba di Pondok Pesantren As-Stressiyah Darul Ubudiyah Sejati Sejomulyo Juwana Pati. Rumusan masalah dalam tulisan ini difokuskan pada dua masalah, yaitu bagaimana pelaksanaan pendidikan spiritual berbasis tarekat bagi pecandu narkoba di Pondok As-Setressiyah Darul Ubudiyah Sejati dan apa faktor pendukung dan penghambat pelaksanaan pendidikan spiritual berbasis tarekat bagi pecandu narkoba di Pondok As-Setressiyah Darul Ubudiyah Sejati. Tulisan ini merupakan hasil penelitian kualitatif dengan menggunakan metode studi kasus. Pengumpulan data menggunakan teknik partisipant observation, wawancara, dan dokumentasi. Sampel sumber data ditentukan secara purposive dan menggunakan teknik snowball. Adapun teknik analisis yang digunakan adalah analisis deskriptif kualitatif dengan pendekatan fenomenologi. Analisis dimulai semenjak di lapangan dan dilakukan secara interaktif dan terus menerus hingga tuntas. Hasil dari penelitian ini adalah bahwa beberapa amalan tarekat ternyata relevan untuk diterapkan dalam pelaksanaan pendidikan spiritual bagi pecandu narkoba. Amalan-amalan tarekat tersebut antara lain: Taubat, Manāqiban, Doa, Dhikir, Tașawwur al-Shaikh, dan Riyāụah.
\end{abstract}

Kata Kunci : Pendidikan Spiritual; Tarekat; Pecandu Narkoba. 


\begin{abstract}
:
This paper intends to provide an overview of the implementation of tarekat-based spiritual education for drug addicts at Pesantren AsStressiyah Darul Ubudiyah Sejati Sejomulyo Juwana Pati. The formulation of the problem focuses on two issues, how the implementation of tarekatbased spiritual education for drug addicts in Pondok As-Setressiyah Darul Ubudiyah Sejati and what are the supporting factors and inhibiting the implementation of tarekat-based spiritual education for drug addicts in Pondok As-Setressiyah Darul Ubudiyah Sejati. This paper is a result of a qualitative research using case study method. In collecting the data, this research used participatory techniques, interviews, and documentation. The sample data source was determined purposively and used the snowball technique. The analysis technique used is descriptive qualitative analysis with phenomenology approach. The analysis begins in the field and is done interactively and continuously until being completed. The result of this research shows that some tarekat practices are relevant to be applied in the implementation of spiritual education for drug addicts. The orders of the tarekat are: Taubat, Manāqiban, Prayer, Dhikir, Tasawwur al-Shaykh, and Riyădah.
\end{abstract}

\title{
Keywords: Spiritual Education; Tarekat; Drug Addicts.
}

\section{A. Pendahuluan}

Bergulirnya proses modernisasi dengan sangat cepat telah merubah paradigma kebanyakan orang menjadi serba materialistis. Meskipun secara kuantitatif, manusia mengalami kemajuan material yang luar biasa, tetapi secara kualitatif justru mengalami krisis yang memilukan. Kemajuan-kemajuan yang dibarengi dengan kemakmuran dan kemudahan hidup ternyata memunculkan kemiskinan baru, yaitu kemiskinan spiritual. Kemajuan ilmu pengetahuan dan teknologi yang tidak dibarengi kematangan jiwa, meminjam istilah Nurcholis Madjid, akan menjadi granat hidup di tangan anak-anak yang dapat membahayakan hidupnya. ${ }^{1}$

Pendapat Madjid di atas didukung oleh Ahmad Mubarok. Dalam analisisnya diungkapkan bahwa sebagian besar gangguan kejiwaan yang dialami manusia modern, seperti kecemasan, kebosanan hidup, atau perilaku menyimpang disebabkan oleh kekeringan dari aspek spiritual. Bahkan, munculnya gangguan fisik disinyalir juga disebabkan oleh faktor-faktor kejiwaan.

\footnotetext{
1 Nurcholish Madjid, Islam Doktrin dan Peradaban: Sebuah Telaah Kritis tentang Masalah Keimanan, Kemanusiaan, dan Kemodernan (Jakarta: Paramadina, 2000), 582.

Jurnal Pendidikan Agama Islam (Journal of Islamic Education Studies)

Volume 5 Nomor 2 (2017)

ISSN(p) 2089-1946\& ISSN(e) 2527-4511

Hal. 162 - 180
} 
Untuk itu, jika ingin menghindari gangguan-gangguan tersebut, maka manusia harus berusaha mendidik dan mengatur jiwanya. ${ }^{2}$

Islam yang menjunjung tinggi prinsip tawāzun sangat memperhatikan aspek keseimbangan dan keharmonisan antara lahir dan batin, fisik dan spiritual. Bahkan, spiritualitas dan Islam adalah dua hal yang tidak mungkin dipisahkan. Islam tanpa spiritualitas bukanlah agama, tapi sekedar simbol-simbol tanpa makna. Islam bukanlah fenomena sejarah yang dimulai 15 abad yang lalu, tetapi merupakan sebuah kesadaran abadi yang bermakna penyerahan diri dan ketundukan. ${ }^{3}$ Berislam, betapapun melibatkan kerja fisik, urusan hati tidak mungkin dapat ditinggalkan begitu saja. Aspek spiritual adalah ruh dalam beragama yang mempengaruhi baik dan buruknya perilaku.

Oleh sebab itu, pendidikan Islam tidak hanya berorientasi pada pendidikan fisikal dan intelektual semata, tetapi juga aspek spiritual sebagai satu kesatuan yang integral dalam diri peserta didik. Namun pada kenyataannya, implementasi pendidikan Islam di lembaga-lembaga pendidikan lebih banyak menonjolkan sifat materialnya daripada sifat spiritualnya. Operasionalisasi pendidikan Islam lebih sering berhenti pada pengembangan fisik dan nalar dan mengorbankan intuisi. Hal ini disinyalir menjadi faktor penyebab gagalnya pendidikan Islam saat ini dalam mencetak generasi yang berakhlak mulia. Dari sinilah kemudian paradigma pendidikan Islam berbasis spiritual muncul. Pendidikan spiritual dipandang sangat krusial untuk menambal lubang yang menganga cukup lebar dari pendidikan Islam.

Dalam konteks pendidikan Islam, Sa'īd Hawwā mengemukakan bahwa Pendidikan spiritual atau al-tarbiyah al-rühiyah adalah upaya pembangunan jiwa individu dalam perjalanan (al-sayr) menuju kedekatan kepada Allah Swt. Spiritual Teaching atau pendidikan spiritual adalah proses merubah individu dari jiwa yang kotor menuju jiwa yang bersih, dari nalar yang belum patuh menuju nalar yang patuh, dan dari hati yang keras menjadi hati yang lembut. Ringkasnya, pendidikan spiritual adalah proses penyempurnaan pribadi manusia menuju kebaikan sesuai al-Qur'an dan Sunnah baik perkataan, tingkah laku dan keadaannya. ${ }^{4}$ Hal ini didukung oleh Erham Wilda bahwa pendidikan spiritual diharapkan mampu mewujudkan kepribadian yang terintegrasi sesuai dengan tuntunan al-Qur'ān dan Hadith, yakni pribadi yang berimbang antara kebutuhan

2 Marwan Salahudin \& Binti Arkuni, "Amalan Tarekat Qadiriyah Wa Naqsabandiyah Sebagai Proses Pendidikan Jiwa di Masjid Babul Muttaqin Desa Kradenan Jetis Ponorogo," Esoterik: Jurnal Akhlak dan Tasawuf, Vol. 2 No.1 (2016), 66.

3 Fathul Mufid, "Spiritual teaching dalam Membentuk Karakter Siswa di SMK Islam Tsamratul Huda Tahunan Jepara," Edukasia: Jurnal Penelitian Pendidikan Islam, Vol. 11, No.2, (Agustus 2016), 256.

${ }^{4}$ Sa'id Hawwā, Tarbiyatunāal-Rūhiyyah (Kairo: Maktabah al-Wahbah, 1992), 69. 
fisik dan spiritual sehingga akan terbentuk manusia yang utuh, baik jasmaniah maupun rohaniah. ${ }^{5}$

Di tengah-tengah kondisi masyarakat yang sakit, pendidikan spiritual akan menjadi sebuah penawar yang ampuh dalam mengatasi masalah-masalah sosial kemasyarakatan akibat modernisasi. Dengan memperbanyak pembinaan dan pembiasaan praktik spiritual, maka akan tumbuh kesadaran dan komitmen ketuhanan yang secara bertahap akan semakin kuat.

Hal ini sebagaimana disampaikan oleh Zakiah Daradjat, bahwa setiap tindakan atau aktivitas spiritual akan membawa pengaruh terhadap kesadaran beragama dan pengalaman beragama pada diri seseorang. Kesadaran beragama adalah bagian dari segi agama yang hadir (terasa) dalam pikiran dan dapat diuji melalui introspeksi, atau dapat dikatakan bahwa ia adalah aspek mental dari aktivitas agama. Sedangkan pengalaman agama adalah unsur perasaan dalam kesadaran beragama yang membawa kepada keyakinan yang dihasilkan oleh tindakan. ${ }^{6}$

Kesadaran dan komitmen ketuhanan tersebut selanjutnya akan menjadi kontrol dan pengendali diri dari perilaku menyimpang. Nilai-nilai agama yang ditanamkan lewat pendidikan dan kegiatan keagamaan akan menjadi kontrol terhadap segala bentuk sikap dan tingkah laku sehari-hari. Bahkan, sebagaimana dikemukakan Uthmān Najāty, berbagai penelitian yang telah dilakukan tentang hubungan antara agama dan kesehatan jiwa menunjukkan adanya indikasi bahwa komitmen ketuhanan mempertinggi kemampuan seseorang dalam mengatasi penderitaan dan mempercepat penyembuhan dari berbagai penyakit. ${ }^{7}$

Hal ini pula yang dilakukan oleh Pondok Pesantren As-Setressiyah Darul Ubudiyah Sejati. Pesantren yang terletak di Dukuh Garuan Desa Sejomulyo Juwana Pati tersebut, semenjak awal berdirinya secara konsisten menampung dan memberikan rehabilitasi terhadap orang-orang dengan perilaku menyimpang seperti para pecandu narkoba, orang-orang stress, dan depresi. Dalam upayanya merehabilitasi para pecandu narkoba, di samping rehabilitasi fisik, pesantren asuhan KH. Fathur Rohman Thoyyib ini juga sangat menekankan pada pendidikan dan pendekatan spiritual. KH. Fathur Rohman Thoyyib atau biasa disapa Mbah Sarimbit yang merupakan seorang mursyid tarekat, menggembleng kejiwaan para santri pecandu narkoba dengan menggunakan metode-metode yang digunakan dalam tarekat seperti taubat, dhikir, riyădah dan lain-lain. Dengan bimbingan dan tuntunan guru mursyid, penggunaan metode-

\footnotetext{
${ }^{5}$ Erham Wilda, Konseling Islami (Yogyakarta: Graha Ilmu, 2009), 65.

6 Zakiah Daradjat, Ilmu Jiwa Agama (Jakarta: Bulan Bintang, 1970), 14.

7 M. Uthmān Najāty, Al-Qur'an dan Ilmu Jiwa, terj. Ahmad Rofi Usmani (Bandung: Pustaka, 1985), 287.
} 
metode tersebut diharapkan dapat menyentuh sisi terdalam kejiwaan dan menguatkan kesadaran ketuhanan para santri agar tidak terjerumus lagi ke dalam lembah hitam.

Berangkat dari uraian tersebut, kajian ini bermaksud untuk mengeksplor dan memberikan gambaran tentang implementasi tarekat dalam pelaksanaan pendidikan spiritual bagi pecandu narkoba di Pondok Pesantren As-Stressiyah Darul Ubudiyah Sejati sekaligus faktor pendukung dan penghambatnya. Hasil kajian ini diharapkan dapat memberikan kontribusi berupa tawaran metodologis dan alternatif model pendidikan spiritual khususnya bagi orang-orang yang memiliki problem kejiwaan.

\section{B. Metode Penelitian}

Penelitian ini termasuk dalam kategori penelitian kualitatif karena berusaha untuk menemukan data dengan terlibat langsung dalam latar belakang masalah serta orang-orang tertentu yang diteliti. Hal ini sesuai dengan definisi yang disampaikan Jane Richie bahwa penelitian kualitatif adalah upaya untuk menyajikan dunia sosial dan prespektifnya di dalam dunia, dari segi konsep, perilaku, persepsi dan persoalan tentang manusia yang diteliti. ${ }^{8}$ Penelitian ini menggunakan. Sebagai penelitian kualitatif, penelitian ini berpijak pada sembilan prinsip penelitian kualitatif, yaitu alamiah (natural inquiry), analisis deduktif, kontak langsung di lapangan, perspektif holistik, perspektif dinamis, orientasi pada kasus unik, ${ }^{9}$ netralitas empatik, fleksibilitas desain, dan periset sebagai instrumen kunci. ${ }^{10}$

Dalam pelaksanaannya, penelitian ini menggunakan metode studi kasus (case study), yaitu metode atau strategi penelitian dan sekaligus hasil penelitian pada kasus tertentu. Studi kasus merupakan suatu penelitian yang dilakukan terhadap suatu "kesatuan sistem". Kesatuan ini dapat berupa program, kegiatan, peristiwa, atau sekelompok individu yang terikat oleh tempat, waktu atau ikatan tertentu. Penelitian model ini diarahkan untuk menghimpun data, mengambil makna, dan memperoleh pemahaman dari kasus tersebut. ${ }^{11}$

Data dalam penelitian ini dikumpulkan dengan teknik observasi peran serta atau partisipant observation, wawancara mendalam, dan dokumentasi. Sumber data bisa berupa ; 1) person atau individu yaitu pelaku pendidikan spiritual meliputi Pengasuh, para Ustadz, dan para santri pecandu Narkoba. 2)

\footnotetext{
${ }^{8}$ Lexy J. Moleong, Metodologi Penelitian Kualitatif (Bandung: Remaja Rosdakarya, 2008), 6.

${ }_{9}^{9}$ Agus Salim, Teori dan Paradigma Penelitian Sosial (Yogyakarta: Tiara Wacana, 2006), 9- 11.

${ }^{10}$ Salim, Penelitian Sosial, 118.

11 Nana Syaodih Sukmadinata, Metode Penelitian Pendidikan (Bandung : Remaja Rosdakarya, 2009), 64.
} 
Place atau tempat yakni Pesantren As-Setressiyah beserta segala aktifitas dan situasi-kondisi di dalamnya. 3) Paper atau dokumen adalah segala dokumen baik yang bersifat kelembagaan ataupun tulisan-tulisan yang berkaitan dengan pesantren As-Stetressiyah.

Sementara sampel sumber data yang dipilih menjadi responden dalam penelitian ini ditentukan secara purposive dan menggunakan teknik snowball sampling. Maksudnya, penentuan sampel sumber data tidak bersifat baku dan permanen, tetapi masih bersifat sementara dan kemungkinan besar akan berkembang setelah peneliti terjun ke lapangan. Sebagai langkah awal saat memasuki lapangan, sampel sumber data hendaknya dipilih dari kalangan yang memiliki power dan otoritas sehingga akan memudahkan peneliti untuk mengumpulkan data kemana saja. ${ }^{12}$ Dalam hal ini, peneliti memilih pengasuh Pesantren yaitu KH. Fathur Rohman Thoyyib sebagai sampel sumber data pada tahap awal penelitian, kemudian dilanjutkan dengan Agus Zubair sebagai pengurus Pesantren, dan Ahmad Saenuri selaku santri pecandu narkoba.

Adapun analisis data yang digunakan dalam penelitian ini adalah teknik analisis deskriptif kualitatif. Analisis data dalam studi kasus biasanya jarang sekali didefinisikan secara tegas dan konkret, karena dalam rumpun pendekatan kualitatif, studi kasus tidaklah bersifat kaku. Ia menawarkan keluwesan dan sewaktu-waktu dapat diubah sesuai dengan perkembangan yang lebih menarik, unik dan penting dari fakta empiris yang tengah dicermati. Hal ini tidak berarti terjadi inkonsistensi, melainkan terhadap fenomena sosial yang menjadi unit analisis lebih dikedepankan dan diutamakan aspek emik ketimbang etiknya. ${ }^{13}$

Sebagaimana penelitian kualitatif kebanyakan, analisa dalam penelitian ini lebih banyak menggunakan teori fenomenologi. Miles dan Huberman mengemukakan bahwa analisis data dalam penelitian kualitatif dilakukan secara interaktif dan terus menerus hingga tuntas, sehingga datanya sudah jenuh. Adapun langkah-langkahnya adalah; Reduksi data yang berarti merangkum dan memilih hal-hal yang pokok. Dilanjutkan langkah kedua yaitu penyajian data dan diakhiri dengan Penarikan kesimpulan dan verifikasi. ${ }^{14}$

Sedangkan untuk uji kredibilitas atau keabsahan data hasil penelitian dilakukan dengan cara; Pertama, memperpanjang pengamatan. Dalam perpanjangan ini, peneliti melakukan pengujian terhadap data, apakah data yang diperoleh setelah dicek ke lapangan benar atau tidak, berubah atau tidak. Bila

\footnotetext{
12 Sugiyono, Metode Penelitian Pendidikan (Bandung: Alfabeta, 2005), 146.

13 Abdul Aziz, "Memahami Fenomena Sosial Melalui Studi Kasus" dalam Analisis Data Penelitian Kualitatif ed. Burhan Bungin (Jakarta : Raja Grafindo Persada, 2010), 33.

14 Sugiyono, Metode Penelitian Kuantitatif, Kualitatif, dan $R \& D$ (Bandung : Alfabeta, 2009), 246.
} 
setelah dicek ternyata benar, berarti data kredibel dan perpanjangan observasi bisa diakhiri. Namun apabila ternyata salah, maka peneliti akan menambah waktu perpanjangan penelitian. Kedua, meningkatkan ketekunan. Peneliti melakukan pemeriksaan dengan membaca ulang hasil wawancara, apakah sudah mendalam atau belum, sesuai dengan tujuan ataukah belum. Bila perlu, peneliti bisa melakukan wawancara ulang atau konfirmasi terkait informasi yang telah didapatkan kepada narasumber pada waktu yang berbeda.

\section{Pondok Pesantren As-Stressiyah Darul Ubudiyah Sejati ; Pendidikan Islam, Spiritualitas dan Rehabilitasi}

Pondok Pesantren As-Stressiyah Darul Ubudiyah Sejati merupakan salah satu pesantren di daerah Pantura yang secara konsisten menampung dan memberikan pelayanan rehabilitasi bagi para pecandu narkoba. Pondok ini didirikan pada tahun 1999 oleh KH. Fathur Rohman Thoyyib atau lebih dikenal dengan panggilan Mbah Sarimbit di dukuh Garuwan Desa Sejomulyo Kecamatan Juwana Kabupaten Pati. ${ }^{15}$ Pendirian Ponpes ini, konon atas perintah langsung dari guru Mbah Sarimbit yaitu KH. Ahmad Fadhil, pengasuh Pondok Pesantren As-Sa'adah desa Asempapan Trangkil Pati.

Sang Pengasuh yakni KH. Fathur Rohman Thoyyib adalah seorang mursyid tarekat Shat\}ariyyah. Ia Mendapatkan ijazah mutlak atau kemursyidan tarekat Shat\}ariyyah dari KH. Abi Syifa' Naufal Abdullah Bendakerep Cirebon. Pergumulannya dengan dunia tasawuf dan hikmah dimulai saat ia duduk di bangku pesantren di bawah asuhan KH. Ahmad Fadhil. Di bawah bimbingan kiai Fadhil ini, ia banyak melakukan khalwat dan meditasi di tempat-tempat keramat. Setelah belajar dari Kiai Fadlil ia kemudian melanjutkan pengembaraan tasawufnya dengan berguru kepada beberapa mursyid tarekat.

Ia juga pernah belajar dan ber-ba'iat kepada beberapa tarekat mu'tabarah, antara lain Tarekat Shādhiliyyah dari KH. Muhaiminan Gunardo Temanggung dan KH. Abdul Haq Dalhar Magelang, Tarekat Naqshabandiyyah Khālidiyyah dari KH. Rahmat Nur Pati, Tarekat Shațariyyah Shādhiliyyah dari KH. Abdul Wahid Dahlan Grobogan dan KH. Hasbullah Cilacap, dan ijazah dhikir 'Alawiyyah dari Habib Anis al-Habsyi Solo. Puncak pengembaraan tasawufnya adalah ketika ia mendapatkan ijazah kemursyidan dari KH. Abi Syifa' Naufal Abdullah Bendakerep Cirebon. ${ }^{16}$

\footnotetext{
15 Dokumentasi di PP. As-Stressiyah Darul Ubudiyah Sejati pada 14 November 2017.

${ }^{16}$ KH. Fathur Rohman Thoyyib, Wawancara, Pati, 14 November 2016.
} 
Berdasarkan pemaparan Agus Zubair, Pengurus PP. As-Stressiyah, saat ini, selain mengurus pesantren dan membina beberapa majlis dhikir, Kiai Fathur Rohman aktif di beberapa organisasi tarekat baik tingkat lokal maupun nasional.

“Di lingkup kabupaten kiai aktif dan menjabat sebagai ketua JATMAN (Jam'iyyah Ahli al-Ṭariqah al-Mu’tabarah al-Nahḍiyyah) Kabupaten Pati. kiai juga aktif di organisasi yang sama dan menjabat sebagai sekertaris JATMAN di tingkat Nasional. Kiai juga duduk dalam jajaran pimpinan persatuan Mursyid Tarekat Shat\}ariyyah se-Asia."17

Sebelum terjun ke dunia pendidikan pesantren dan menjadi guru mursyid, Kiai Fathur Rohman pernah bekerja di pabrik Kuningan di Jepara. Berikut hasil wawancara penulis:

"Suatu waktu saya diperintahkan Kiai Fadhil untuk bermeditasi selama 2 bulan. Awalnya saya tidak begitu fasih membaca kitab kuning, setelah meditasi tersebut merasa tercerahkan dan fasih membaca kitab kuning. Setelah meditasinya rampung, saya kemudian diperintahkan untuk mendirikan sebuah mushola di kampung Garuwan sebagai pusat dakwah. Awal berdirinya mushola, jamaah hanya 4 orang, lalu bertambah 10 orang hingga akhirnya ia mampu membeli tanah beberapa hektar untuk mendirikan pondok pesantren."18

Ketika masih berupa musholla, Mbah Sarimbit pernah mengalami beberapa penolakan dari warganya sendiri. Tuduhan gila dan semacamnya juga sering dialamatkan kepadanya karena amalan-amalan tarekat yang dilakukan tidak masuk akal bagi orang awam. Apalagi jika melihat penampilan Mbah Sarimbit yang berambut gondrong dan tampak aneh tersebut, agaknya memang jauh dari kesan seorang kiai. Namun ketika jama'ahnya semakin bertambah, apalagi yang dari luar kota, maka kepercayaan masyarakat sekitar juga semakin bertambah.

Pesantren As-Stressiyah didirikan oleh Mbah Sarimbit dengan niat luhur yakni untuk membantu orang-orang yang mengalami gangguan mental seperti pecandu narkoba dan orang-orang stress. Menurutnya, pecandu narkoba adalah orang yang sedang sakit fisik dan jiwanya sehingga membutuhkan pengobatan dan pemulihan secara intensif. Tentu saja biaya yang dibutuhkan juga tidak sedikit karena membutuhkan waktu yang lama untuk bisa sembuh total. Sementara, menurut Mbah Sarimbit, pengobatan di Rumah Sakit atau Panti seringkali tidak bisa memberikan kesembuhan total. Banyak pasien yang tidak benar-benar sembuh, sehingga sepulang dari pengobatan, penyakit atau kebiasaan buruknya akan kambuh lagi. Hal ini disebabkan, salah satunya, oleh metode pengobatan yang cenderung terlalu mengandalkan sisi medis dan kurang

\footnotetext{
${ }^{17}$ Agus Zubair, Wawancara, Pati, 14 November 2016.

18 KH. Fathur Rohman Thoyyib, Wawancara, Pati, 14 November 2016.

Jurnal Pendidikan Agama Islam (Journal of Islamic Education Studies)

Volume 5 Nomor 2 (2017)

ISSN(p) 2089-1946\& ISSN(e) 2527-4511

Hal. 168 - 180
} 
menyentuh sisi spiritual. Padahal kedua-duanya perlu diberikan porsi yang cukup, karena penyakit jiwa dan kecanduan narkoba adalah penyakit spiritual.

Melihat fenomena itu, Mbah Sarimbit berkomitmen untuk memberikan layanan pendidikan dan rehabilitasi bagi para pecandu narkoba atau orang dengan gangguan kejiwaan lewat pesantren dengan gratis dan tanpa biaya sedikitpun. Namun demikian, KH. Fathur Rohman Thoyyib tidak menutup pintu pesantrennya untuk santri dari kalangan orang waras. Ia juga memfasilitasi santri secara cuma-cuma yang memang mau datang hanya untuk mengaji dan menimba ilmu agama, bukan berobat kepadanya. ${ }^{19}$

Saat ini, Ponpes As-Stresiyyah asuhan Mbah Sarimbit telah memiliki beberapa kompleks dengan puluhan santri, baik dari dalam maupun luar Pati atau bahkan dari luar pulau. Sebagian dari yang menetap adalah pecandu narkoba dan penderita gangguan jiwa yang mondok untuk berobat dan bertobat. Sedangkan sebagian lain adalah santri biasa yang memang ingin nyantri. Di luar itu, justru yang paling banyak adalah santri kalong (istilah untuk santri yang tidak menetap) yang rutin datang mengaji kitab atau tarekat. Ponpes AsStressiyyah Darul Ubudiyah Sejati merupakan satu dari sedikit pesantren rehabilitasi gangguan jiwa dan narkoba di Pantura raya. Meskipun terletak di pelosok, pesantren ini sudah dikenal luas oleh masyarakat bahkan hingga ke luar Jawa.

\section{Pendidikan Spiritual Berbasis Tarekat bagi Pecandu Narkoba di Ponpes As- Stressiyyah Darul Ubudiyah Sejati}

Dewasa ini, pendidikan Islam dianggap telah gagal dalam mengemban misi Islam yaitu membentuk generasi muslim yang berakhlak mulia. Banyak kalangan menganggap kegagalan ini dipicu oleh paradigma pendidikan yang tidak tepat. Paradigma yang ada selama ini dipandang lebih berorientasi kepada hafalan dan pemahaman, bukan sikap dan perilaku. Sasaran pendidikan hanya menyentuh ranah kognitif semata, tidak sampai pada psikomotorik, apalagi afektif. Banyak orang yang sangat fasih membaca dalil, tetapi tidak mampu mengamalkannya. Banyak yang fasih membaca lafadz do'a, tetapi tidak bisa memahami esensi berdo'a. Maka, perubahan paradigma pendidikan Islam semacam ini diyakini menjadi sebuah keharusan.

Paradigma dalam pendidikan Islam yang dianggap mampu menjadi alternatif solusi dari problematika di atas adalah pendidikan spiritual. Pendidikan spiritual atau al-Tarbiyah al-Rühiyah adalah pendidikan jiwa yang menghendaki perbaikan secara bertahap dengan cara mengembangkan potensi

${ }^{19}$ KH. Fathur Rohman Thoyyib, Wawancara, Pati, 14 November 2016. 
rohani agar lebih mencintai Allah dan Rasul-Nya. ${ }^{20}$ Tujuannya adalah untuk membangun jiwa individu dan mengarahkannya pada perilaku dan akhlak yang mulia menuju terbentuknya manusia yang utuh, baik secara material maupun spiritual. Pendidikan spiritual juga dimaksudkan untuk mencetak individu yang jiwanya tenang penuh semangat dalam menatap kehidupan dan tidak mudah jatuh saat berhadapan dengan halangan dan rintangan. ${ }^{21}$

Dalam konteks Islam, pendidikan spiritual dapat dilaksanakan dengan berbagai metode. Sa'id Hawwā lebih cenderung kepada metode yang digunakan oleh para sufi dalam pendidikan spiritual. Menurutnya, para sufi telah mewarisi strategi pendidikan dan penyucian jiwa dari Rasulullah. Mereka mendalami pendidikan spiritual lewat jalan tasawuf selama berbabad-abad dan mempraktikkannya. Untuk pengembangan potensi spiritual individu, bisa dilakukan dengan mengikuti amalan-amalan tasawuf seperti dhikir, do'a, taubat, dan sebagainya. Tasawuf yang lebih menekankan amalan-amalan dan suluk semacam itu dalam khazanah ilmu tasawuf disebut tasawuf amali yang kemudian dilembagakan dalam tarekat.

Semula, suatu tarekat hanya berupa "jalan atau metode yang ditempuh oleh seorang sufi secara individual”. Kemudian para sufi itu mengajarkan pengalamannya itu kepada murid-muridnya, baik secara individual maupun secara kelompok. Dari sini terbentuklah suatu tarekat dalam bentuk kedua, yaitu "jalan menuju Tuhan dibawah bimbingan seorang guru”. Selanjutnya dari pengertian demikian muncul lagi pengertian tarekat dalam bentuk ketiga, yakni, “organisasi sejumlah orang yang berusaha mengikuti kehidupan tasawuf". ${ }^{22}$

Dalam pandangan Mustafa Zahri, tarekat adalah jalan atau petunjuk dalam melakukan sesuatu ibadah sesuai dengan ajaran yang dicontohkan oleh Nabi Muhammad dan dikerjakan oleh sahabat-sahabatnya, tabi'in dan tabi'î altabi'in turun-temurun sampai kepada guru-guru secara berantai sampai pada masa kita ini. ${ }^{23}$ Lebih khusus lagi tarekat berarti sistem dalam rangka mengadakan latihan jiwa, membersihkan diri dari sifat-sifat yang tercela dan mengisinya dengan sifat-sifat yang terpuji dan memperbanyak dhikir dengan penuh ikhlas semata-mata untuk mengharapkan bertemu dengan dan bersatu secara ruhiah dengan Tuhan. ${ }^{24}$ Dengan demikian, mengikuti suatu tarekat berarti

20 Abd al-Ḥamīd al-Șaid al-Zintāny, Usūs al-Tarbiyah al-Islāmiyyah fi al-Sunnah al-Nabawiyyah (Tunis: Al-Dar al-'Arabiyah li al-Kitab, 1993), 326.

${ }^{21}$ Mufid, "Spiritual Teaching", 261.

22 Yunasril Ali, "Tasawuf", dalam Ensiklopedi Tematis Dunia Islam, ed. Taufik Abdullah (Jakarta: Ichtiar Baru Van Houve, 2002), 147.

${ }^{23}$ Mustafa Zahri, Kunci Memahami Ilmu Tasawuf (Surabaya: Bina Ilmu, 1995), 56.

24 Zahri, Kunci Memahami Ilmu Tasawuf, 57.

Jurnal Pendidikan Agama Islam (Journal of Islamic Education Studies)

Volume 5 Nomor 2 (2017)

ISSN(p) 2089-1946\& ISSN(e) 2527-4511

Hal. 170 - 180 
melakukan olah batin, latihan-latihan (riyādah), dan perjuangan yang sungguhsungguh (mujāhadah) di bidang kerohanian.

Tarekat juga memiliki beberapa unsur dalam proses pembinaan spiritual. Pertama, Guru yang disebut Mursyid atau Shaikh, dan wakilnya disebut Khalifah yang bertanggungjawab atas proses pembinaan. Menurut ketentuan tarekat pada umumnya, seorang Shaikh sangat menentukan kemajuan spiritual muridnya. Mengikuti sebuah tarekat tanpa mempunyai seorang mursyid adalah mustahil. ${ }^{25}$ Kedua, murid atau lazim disebut sālik yaitu para pengikut tarekat. Seorang salik disyaratkan harus berjanji setia kepada dirinya dihadapan mursyid, bahwa ia akan mengamalkan segala bentuk amalan dan wirid yang telah diajarkan guru kepadanya dengan sungguh-sungguh. Janji setia itu dikenal dengan istilah bai'at.

Ketiga, Zäwiyah adalah majelis tempat para salik mengikuti proses pembinaan dan menjalankan amalan-amalan tarekat. Keempat, amalan atau kurikulum dalam tarekat yang harus dijalani oleh para murid. Tiap tarekat memiliki amalan atau ajaran wirid tertentu, simbol-simbol kelembagaannya, tata tertibnya dan upacara-upacara lainnya yang membedakan antara satu tarekat dengan tarekat lainnya. Kelima, adab atau etika murid. Secara umum, keberadaan murid di hadapan gurunya ibarat mayat yang tidak punya daya apapun di tangan orang yang merawatnya. Penghormatan dan ketaatan seorang murid kepada mursyid tarekat merupakan komponen penting dalam tarekat, karena perkembangan murid sangat bergantung pada sang mursyid.

Semenjak kemunculannya, tarekat sebagai sebuah institusi hingga saat ini telah membuktikan diri menjadi salah satu lembaga pendidikan Islam yang berhasil. Tarekat dipandang cukup sukses dalam menanamkan nilai-nilai keislaman dan merubah perilaku para pengikutnya. Bahkan, capaian tarekat dalam hal perubahan perilaku telah melampaui pendidikan formal dengan sangat jauh. Tarekat mampu merubah seorang preman menjadi orang yang berguna, sementara pendidikan formal justru sebaliknya.

Bukti bahwa tarekat telah melangkah jauh dari pendidikan formal adalah adanya pesantren-pesantren berbasis tarekat yang menjadi pusat rehabilitasi perilaku menyimpang. Sebut saja Pondok Pesantren Suryalaya dengan tarekat Qādiriyyah Naqshabandiyyah yang kiprahnya dalam penyembuhan perilaku menyimpang telah masyhur di seantero negeri ini. Di luar itu, banyak lagi pesantren berbasis tarekat seperti pesantren Suryalaya, hanya saja tidak begitu populer.

Ponpes As-Stressiyah Darul Ubudiyah Sejati juga merupakan pondok pesantren berbasis tarekat yang menampung santri-santri tidak normal seperti

25 Martin Van Bruinessen, Tarekat Naqsyabandiyah di Indonesia (Bandung: Mizan, 1992), 86. 
pecandu narkoba, orang stress, dan depresi. Berbeda dengan pesantren Suryalaya yang berbasis tarekat Qādiriyyah Naqshabandiyyah, Ponpes AsStressiyah berdiri di atas ajaran tarekat Shațariyyah. Dalam rangka merehabilitasi para santri pecandu narkoba dari sisi spiritual, pesantren ini menggunakan beberapa metode dan amalan tarekat Shatariyyah. Tentunya dosis amalan yang diberikan oleh mursyid kepada para santri pecandu narkoba berbeda dengan orang normal. Beberapa amalan dalam tarekat Shatariyyah yang digunakan dalam rangka pendidikan spiritual bagi pecandu narkoba adalah sebagai berikut:

1. Taubat

Langkah awal atau maqām awwal dalam menekuni tarekat dimulai dengan taubat yaitu mengakui, menyesali, dan berkomitmen untuk tidak mengulangi kesalahan lagi. Taubat adalah bagian dari usaha manusia untuk menyucikan jiwa dari sifat-sifat yang tidak terpuji. Dalam tasawuf, taubat tidak hanya menyesali dosa, baik besar ataupun kecil, tetapi harus mengikuti tuntunan dari pembimbing spiritual, yaitu guru mursyid. Taubat sebagai metode penyucian jiwa tentunya berpengaruh kepada perilaku bahkan kepribadian seseorang. Dengan taubat, maka rohani manusia akan menjadi suci seperti bayi yang baru dilahirkan. Jiwa manusia atas bimbingan guru mursyid akan menjadi seperti kain putih yang belum ternoda oleh kotoran.

Menurut Agus Zubair, dalam menangani santri pecandu narkoba, pertama kali yang dilakukan oleh KH. Fathur Rohman Thoyyib adalah mengajak mereka untuk bertaubat. Dalam melaksanakan taubat tersebut, para santri diajak untuk mengingat kembali dan menyesali dosa-dosa yang telah diperbuat. Tidak hanya itu, taubat juga harus dibarengi dengan komitmen untuk tidak mengulangi dosa yang diperbuat, mengembalikan hakhak orang yang telah dianiaya, dan memohon maaf orang yang pernah dianiaya. Namun sebelum melakukan taubat, santri dianjurkan untuk mandi taubat dan menyucikan diri dengan berwudlu. Oleh KH. Fathur Rohman Thoyyib, para santri nombo memang tidak diwajibkan untuk bai'at tarekat terlebih dahulu, karena kondisi kejiwaan yang masih sangat lemah. Ia tidak pernah memaksa siapapun untuk mengikuti tarekat yang ia ajarkan. ${ }^{26}$

2. Pembacaan Manāqib

Pembacaan manāqib atau biasa disebut manāqiban menjadi salah satu acara penting bagi para penganut tarekat. Manāqiban merupakan tradisi pokok tarekat yang biasa dilaksanakan mingguan, bulanan, atau tahunan di rumah para mursyid dan dihadiri para pengikut. Tujuan pembacaan manāqib pada umumnya adalah untuk ber-tawassul dengan cara membaca sejarah

${ }^{26}$ Agus Zubair, Wawancara, Pati, 6 Desember 2016.

Jurnal Pendidikan Agama Islam (Journal of Islamic Education Studies)

Volume 5 Nomor 2 (2017)

ISSN(p) 2089-1946\& ISSN(e) 2527-4511

Hal. 172 - 180 
hidup para wali atau Shaikh tarekat dalam memohon kepada Allah SWT. Selain dilaksanakan secara umum, manāqiban juga terkadang dilaksanakan pada momen-momen tertentu atau untuk tujuan-tujuan tertentu seperti pindah rumah, khitanan, pernikahan, dan lain-lain.

Adapun manāqiban yang dilakukan di PP. As-Stressiyah untuk pecandu narkoba biasanya dilakukan untuk santri nombo saat mereka pertama kali masuk ke pesantren. Manāqiban dilakukan pada hari weton kelahiran santri yang bersangkutan dan dihadiri oleh kedua orang tua santri yang bersangkutan. Hal ini sebagaimana disampaikan oleh KH. Fathur Rohman Thoyyib:

"Bagi santri nombo atau orang yang ingin berobat, biasanya dicari wetonnya dulu kemudian dibancaki, dimanaqibi bersama kedua orang tuanya. Baik anak ataupun kedua orangtuanya diruwat, didoakan dan dimintakan karomah para wali."27

Pembacaan manāqib untuk santri pecandu narkoba ini bertujuan untuk mendoakan santri dengan ber-wasîlah kepada para wali, khusunya wali yang manāqib-nya dibaca sekaligus mengharap pancaran karāmah dari sang wali agar dapat menembus kejiwaan santri. Setelah menjadi santri pondok, selanjutnya santri yang bersangkutan diwajibkan untuk mengikuti kegiatan manāqiban rutin setiap hari Ahad Paing.

3. Doa

Dalam ajaran tasawuf, mursyid memiliki peranan penting dalam pembinaan rohani murid. Oleh karenanya, selain memberikan pembinaan secara langsung lewat pengajian atau talqīn wirid, guru mursyid juga senantiasa mendo'akan para muridnya agar jiwanya menjadi bersih. Doa dari sang mursyid, merupakan elemen penting dalam tarekat dan sangat berpengaruh terhadap hierarki perkembangan kejiwaan sang murid.

“..Dalam upaya menyucikan kejiwaan para murid, saya juga senantiasa mendoakan para murid dalam setiap kesempatan. Khusus bagi santri pecandu narkoba, selain doa rutin, ia juga membacakan doa khusus yaitu hizib bahr."28

Hizib bahr ini dibacakan dalam sewadah air kemudian diminumkan dan dibasukan ke muka para santri yang bermasalah. Hizib ini juga di-talqīnkan kepada para santri untuk kemudian dibaca seusai shalat subuh dan maghrib. Hizib baḥr merupakan hizib (doa) gubahan Shaikh Abu al-Hasan alShādhily yang di-talqīn langsung oleh Rasulullah secara gaib lewat

${ }^{27}$ KH. Fathur Rohman Thoyyib, Wawancara, Pati, 9 Desember 2016.

${ }^{28}$ KH. Fathur Rohman Thoyyib, Wawancara, Pati, 9 Desember 2016.

Jurnal Pendidikan Agama Islam (Journal of Islamic Education Studies)

Volume 5 Nomor 2 (2017)

ISSN(p) 2089-1946\& ISSN(e) 2527-4511 
meditasinya. Beberapa keutamaan hizib ini antara lain dapat menjadi obat dari berbagai penyakit hati dan melindungi dari berbadai godaan makhluk gaib.

\section{Dhikir}

Para penganut tarekat Shațariyah meyakini bahwa jalan menuju Allah sebanyak hembusan nafas manusia. Artinya, untuk menuju Allah, banyak cara yang bisa dilakukan, tidak harus dengan mencapai fanā'. Akan tetapi jalan yang paling utama adalah dengan selalu mengingat Allah dengan ber-dhikir. Dhikir berfungsi untuk membangkitkan kesadaran akan Allah SWT. Kesadaran ilahiah tersebut akan menjadi kendali dan kontrol bagi perilaku manusia. Semakin tebal kesadaran tersebut, maka semakin terkontrol pula perilaku manusia.

Selain itu, menurut KH. Fathur Rohman Thoyyib, mengingat Allah adalah obat, terutama bagi manusia yang jiwanya telah ternoda oleh nafsu. Para pecandu narkoba adalah orang-orang yang jiwanya telah dikalahkan oleh nafsunya. Mereka terjerembab ke dalam jurang narkoba, salah satunya karena tidak bisa mengontrol nafsunya. Maka obat bagi jiwa para pecandu narkoba yang telah rusak jiwanya karena nafsu adalah dhikir. Dhikir dapat mengembalikan kesucian jiwa dan mengendalikan nafsu. ${ }^{29}$

Oleh karenanya, dalam tarekat Shatariyyah tingkatan dhikir disesuaikan dengan tingkatan nafsu manusia. Nafsu menurut tarekat Shațariyyah ada tujuh macam, yaitu Ammārah, Lawwāmah, Mulhimah, Mutma'innah, Rāụiyah, Marḍyyah, dan Kämilah. Untuk mengendalikan tujuh nafsu itu dan membawa manusia kembali kepada jalan Allah, ada tujuh tingkatan dhikir, yaitu dhikir Tawaf, Nafi Ithbät, Ithbāt Faqat, Ismu Dhàt, Taraqqī, Tanāzul, dan Isim Ghaib.

Oleh KH. Fathur Rohman Thoyyib, ketujuh dhikir tersebut tidak diwajibkan semuanya kepada santri pecandu narkoba, tetapi hanya dhikir Nafi Ithbät dan Ismu Dhät. Dhikir Nafi Ithbāt adalah dhikir dengan lafadz Là Ilāha Illa Allāh dengan cara mengeraskan suara lafadz Nafi-nya, yaitu Lā Ilāha. Sementara lafadz Illa Alläh atau lafadz Ithbät diucapkan dengan pelan-pelan seolah-olah memasukkan asma Allah ke dalam sanubari yang paling dalam. Dalam pengamalannya, dzikit nafi Ithbät dipadukan oleh KH. Fathur Rohman Thoyyib dengan beberapa dhikir lain dan shalawat. Adapun dhikir ismu dzat adalah dhikir dengan lafadz Allah yang dihujamkan ke tengah-tengah dada, tempat bersemayamnya ruh yang menandai adanya hidup dan kehidupan manusia. Kedua dhikir ini wajib diamalkan oleh santri nombo setiap habis

\footnotetext{
${ }^{29}$ KH. Fathur Rohman Thoyyib, Wawancara, Pati, 9 Desember 2016.

Jurnal Pendidikan Agama Islam (Journal of Islamic Education Studies)

Volume 5 Nomor 2 (2017)

ISSN(p) 2089-1946\& ISSN(e) 2527-4511

Hal. 174 - 180
} 
maghrib namun dengan hitungan yang berbeda-beda sesuai kemampuan dan kondisi masing-masing santri.

"Dhikir Nafi Ithbät ditujukan untuk membentengi diri dari serangan nafsu lawwāmah, yaitu nafsu yang mengajak kepada kemaksiatan dan perkara hina.

Sementara dhikir Ismu Dzat diperuntukkan untuk membangkitkan dan mengembangkan nafsu mutma'innah, yaitu nafsu yang tenang, yang mengajak manusia pada kebaikan." 30

Pembiasaan atas kedua jenis dhikir tersebut diharapkan dapat membuahkan kesadaran ketuhanan dan perubahan perilaku santri pecandu narkoba.

5. Tasawwur al-Shaikh

Taşawwur al-Shaikh dalam bahasa tarekat sering juga disebut rābitah yang berarti ikatan atau keterkaitan. Dalam term tarekat, rābitah sering dimaknai sebagai ikatan atau keterkaitan rohaniah antara guru mursyid dan murid. Metode melakukan rābitah adalah dengan selalu membayangkan sosok guru mursyid berada di hadapan murid baik ketika dhikir ataupun di luar dhikir, sehingga seolah-olah guru selalu membimbing setiap langkah murid. Dengan demikian, murid selalu merasa dibimbing dan diawasi oleh sang guru sehingga tidak akan melakukan hal-hal di luar ketaatan kepada sang guru. Kecuali itu, rābitah juga merupakan upaya untuk menanamkan keteladanan sang guru kepada murid. Dengan selalu membayangkan guru, murid akan selalu berusaha untuk mengingat dan meneladani setiap perkataan dan perbuatan sang guru. Semakin kuat ikatan batin mursyid dengan murid, maka semakin cepat ia menuju kepada Allah SWT.

Amalan Tasawwur al-Shaikh ini diajarkan kepada setiap penganut tarekat Shatariyyah baik santri pondok ataupun masyarakat umum. Amalan ini wajib dilaksanakan setiap kali mengamalkan wirid dan dianjurkan di setap waktu di luar wirid. Tujuannya agar murid tarekat merasa selalu terkoneksikan kejiwaannya dengan cahaya sang guru mursyid. Bagi santri pecandu narkoba, amalan rābitah diharapkan dapat menjadi semacam bimbingan atau pengawasan dari guru kepada santri baik saat masih menjalani masa rehabilitasi maupun nanti setelah sembuh.

6. Riyậ̣ah

Salah satu ajaran dalam sulūk (perjalanan) yang dilakukan para penganut tarekat adalah riyạ̣̄h. Riyạ̄ah bisa diartikan sebagai latihan. Riyădah biasanya dilakukan untuk melatih mengendalikan diri dan menahan nafsu dari keinginan dan kenikmatan sesaat. Dengan riyāọah diharapkan

${ }^{30}$ KH. Fathur Rohman Thoyyib, Wawancara, Pati, 9 Desember 2016. 
dapat menjadikan hati dan jiwa menjadi bersih dan suci dari segala kepentingan duniawi. Dalam tarekat Shațariyyah, riyāọah dilakukan dengan berbagai bentuk seperti puasa dalam hitungan waktu tertentu, menahan tidur, atau dengan menghindari makanan-makanan tertentu.

KH. Fathur Rohman Thoyyib juga menerapkan metode riyādah dalam mendidik santri pecandu narkoba. Agus Zubair, salah satu pengurus mengatakan:

"Santri pecandu narkoba harus meninggalkan makanan yang tidak alami atau mengandung obat-obatan kimia seperti mie instan atau ayam pedaging, termasuk penyedap rasa atau obat masak. Istilahnya kalau dalam dunia pesantren namanya nyirih." 31

Riyạ̣̄h ini dimaksudkan agar santri dapat menahan diri dari kenikmatan makanan, sehingga aktifitas makan bukanlah untuk mencari kenikmatan tetapi karena kebutuhan. Dengan begitu, diharapkan santri dapat menahan diri dari segala aktifitas konsumtif untuk mencari kenikmatan, termasuk mengkonsumsi narkoba. Selain itu, tujuan menghindari makanan berbau kimia adalah untuk membersihkan perut, tubuh, dan darah dari obatobatan sehingga bagian dalam tubuh bisa benar-benar bersih dari segala yang berbau obat.

\section{E. Faktor Pendukung dan Penghambat Pelaksanaan Pendidikan Spiritual Berbasis Tarekat bagi Pecandu Narkoba di Ponpes As-Stressiyah}

Ada beberapa faktor yang turut mendukung kelancaran pendidikan spiritual di pesantren As-Stressiyah bagi pecandu narkoba. Pertama, faktor kepemimpinan sang kiai. Kiai merupakan figur sentral yang menjadi nyawa sekaligus motor penggerak pesantren. Eksistensi dan kemajuan sebuah pesantren bahkan sangat dipengaruhi oleh figur dan kharisma kiainya. Semakin tinggi keilmuan dan kemasyhuran seorang kiai, maka semakin besar pula minat masyarakat untuk belajar di pesantrennya. Begitu pula, keberhasilan pembelajaran pesantren juga sangat bergantung kepada konsistensi kiai dalam membimbing dan mendidik santrinya.

KH. Fathur Rohman Thoyyib adalah sosok kiai yang lain daripada yang lain. Meskipun terlihat nyentrik karena berambut gondrong, tetapi sikap dan akhlaknya jauh dari kata sangar. Sebagai seorang pengasuh pesantren sekaligus guru mursyid tarekat, KH. Fathur Rohman Thoyyib merupakan sosok yang penuh kasih sayang, lemah lembut, dan sabar dalam mengayomi setiap santri atau

${ }^{31}$ Agus Zubair, Wawancara, Pati, 6 Desember 2016.

Jurnal Pendidikan Agama Islam (Journal of Islamic Education Studies)

Volume 5 Nomor 2 (2017)

ISSN(p) 2089-1946\& ISSN(e) 2527-4511

Hal. 176 - 180 
pengikutnya. Dengan kelembutan dan kasih sayang pula, ia membimbing dan mendidik santri-santrinya.

Hal ini sesuai dengan apa yang disampaikan Agus Zubair berikut ini:

"Dalam membimbing santri yang tidak normal, tentu dibutuhkan kesabaran yang luar biasa. Uniknya, untuk semua itu, Kiai Fathur Rohman tidak mau memungut biaya serupiah pun dari para santrinya. Ia membuka pintu pesantren selebarlebarnya bagi siapa saja yang membutuhkan, tanpa memandang latar belakangnya, baik atau buruk, muslim atau non muslim dengan cuma-cuma."32

Kedua, di bawah pengasuh, faktor pendukung pendidikan di pesantren adalah pengurus pesantren. Sebagai pemegang kebijakan tertinggi di bawah pengasuh pesantren, dewan pengurus memegang peranan penting demi keberlangsungan dan kelancaran proses belajar mengajar di lembaga pendidikan tersebut. Dewan pengurus adalah pihak yang paling bertanggung jawab atas terselenggaranya kegiatan pembelajaran di Ponpes As-Stressiyah, karena pengasuh tidak begitu banyak waktu untuk mengurus manajemen pesantren.

Untuk menjaga kelancaran kegiatan pembelajaran, dewan pengurus selalu melakukan monitoring dan kontrol terhadap keseharian santri, baik di luar ataupun di dalam pembelajaran. Selain itu, untuk ketertiban pesantren, pengurus juga melakukan penyisiran ke setiap komplek untuk memastikan bahwa semua santri mengikuti kegiatan pembelajaran, kecuali santri nombo yang dipandang masih lemah kejiwaannya atau belum mampu menyesuaikan diri dengan lingkungan pesantren dan tidak diwajibkan mengikuti ritual-ritual tarekat atau kegiatan lain.

Ketiga, selain dua figur di atas, kurikulum pembelajaran juga turut menentukan keberhasilan sebuah proses pembelajaran. Kurikulum adalah seperangkat pengalaman pembelajaran yang terarah dan terencana secara terstruktur dan tersusun secara sistematis untuk mencapai tujuan pembelajaran. Di Ponpes As-Stressiyah, kurikulum pendidikan spiritual yang digunakan dalam kegiatan pembelajaran bagi pecandu narkoba adalah kurikulum berbasis tarekat. Baik materi ataupun metode yang diterapkan mengacu kepada ajaran tarekat Shat\}ariyyah. Namun demikian, tidak semua ajaran dalam tarekat tersebut relevan untuk diterapkan dalam pembelajaran santri pecandu narkoba.

Dalam dunia tarekat, guru mursyid diibaratkan seperti seorang dokter. Ialah yang paling mengerti dan memahami kondisi kejiwaan muridnya. Ia pula yang mengetahui dosis amalan tarekat yang dibutuhkan oleh jiwa-jiwa muridnya. Oleh karenanya, KH. Fathur Rohman Thoyyib tidak pernah memberikan materi pendidikan spiritual yang sama pada setiap santrinya. Ia

${ }^{32}$ Agus Zubair, Wawancara, Pati, 9 Desember 2016. 
selalu menyesuaikan dosis amalan tarekat dengan tingkat perkembangan kejiwaan santri nombo. Sebagai contoh, santri pecandu narkoba yang baru tidak akan dibebani dengan amalan tarekat yang terlalu banyak karena kejiwaan mereka masih sangat lemah. Mereka juga tidak diwajibkan mengikuti ritualritual tarekat atau kegiatan pembelajaran lain. Begitu pula, amalan tarekat bagi santri pecandu narkoba yang telah lama juga disesuaikan dengan kemampuan dan perkembangan kejiwaan mereka.

Adapun hal yang ditemui oleh pesantren dalam melaksanakan pendidikan spiritual bagi santri pecandu narkoba adalah kurangnya minat dan motivasi santri nombo. Dalam proses pembelajaran, minat santri memegang peranan yang sangat penting. Minat dalam diri santri memberikan inspirasi besar untuk selalu belajar dan belajar di setiap kesempatan. Sementara motivasi akan memberikan dorongan kepada santri untuk menyelesaikan pembelajaran dan menggapai keberhasilan. Namun demikian, minat dan motivasi tidak selalu ada dalam diri peserta didik. Maka, setiap guru harus pandai-pandai mengelola pembelajaran agar dapat merangsang dan menumbuhkan minat dan motivasi peserta didik.

Berikut hasil wawancara penulis dengan Ahmad Saenuri, salah seorang pecandu Narkoba di pondok pesantren As-Stressiyah:

"Saat pertama kali masuk ke pesantren, selain pecandu narkoba, saya juga memiliki fisik dan kejiwaan yang lemah. Tubuh saya lemas dan emosi mereka tidak stabil, tidak semangat dan mudah marah."33

Keadaan inilah yang menyebabkan kurangnya minat dan motivasi belajar santri. Di awal santri masuk pesantren, keadaan ini sangat mengganggu dan menghambat kegiatan pembelajaran. Oleh karenanya, KH. Fathur Rohman Thoyyib tidak membebankan amalan tarekat yang terlalu berat kepada santri nombo yang masih baru. Mereka mendapatkan perlakuan yang berbeda dari santri nombo yang memang sudah cukup lama di pesantren, yakni bimbingan dan pembinaan intensif secara langsung dari sang mursyid. Dengan sistem semacam ini, para santri pecandu narkoba lambat laun kondisi para santri pecandu narkoba dapat pulih, baik secara fisik maupun kejiwaan.

\section{F. Kesimpulan}

Pondok Pesantren As-Stressiyah Darul Ubudiyah Sejati adalah salah satu Pondok Pesantren salaf di kawasan Pantura yang konsen terhadap rehabilitasi dan pendidikan para santri dengan latar belakang yang kelam, seperti preman,

\footnotetext{
${ }^{33}$ Ahmad Saenuri, Wawancara, Pati, 9 Desember 2016.

Jurnal Pendidikan Agama Islam (Journal of Islamic Education Studies)

Volume 5 Nomor 2 (2017)

ISSN(p) 2089-1946\& ISSN(e) 2527-4511

Hal. 178 - 180
} 
pecandu narkoba, dan penderita gangguan kejiwaan. Dalam upaya merehabilitasi dan mendidik para santri pecandu narkoba, Ponpes As-Stressiyah lebih menekankan pada pendekatan spiritual dengan tarekat sebagai acuannya. Adapun tarekat yang menjadi acuan pendidikan spiritual adalah tarekat Shatariyyah dengan sang pengasuh, yaitu KH. Fathur Rohman Thoyyib sebagai guru mursyidnya.

Beberapa amalan dalam tarekat Shațariyyah yang diterapkan sebagai dalam pelaksanaan pendidikan spiritual bagi santri pecandu narkoba antara lain: 1) Taubat dengan mengakui segala kesalahan dan dengan melakukan ritual mandi taubat. 2) Dhikir nafi ithbät dan ismu dhät setiap habis maghrib bagi santri pecandu narkoba dengan hitungan dhikir yang berbeda-beda. 3) Tasawwur alShaikh yaitu dengan mengingat dan membayangkan wajah guru baik dalam menjalankan ritual tarekat maupun di luar ritual. 4) Riyădah atau melatih diri untuk mengendalikan nafsu dengan meninggalkan makanan yang mengandung bahan kimia dan penyedap rasa. 5) Doa dilakukan dengan membacakan hizb bahr ke dalam sewadah air yang kemudian diminum dan dibasuhkan ke wajah santri nombo. 6) Pembacaan Manāqib dilakukan pada saat pertama kali santri pecandu narkoba masuk ke pesantren dan setiap hari Ahad Paing.

Metode dan amalan tarekat di atas patut dilirik sebagai salah satu alternatif model pendidikan spiritual. Tarekat, apapun namanya, bisa menjadi salah satu solusi atas kegagalan pendidikan islam dalam menumbuhkan akhlak mulia pada generasi milenial saat ini. Para sufi pengamal tarekat mewarisi metode dan amalan tarekat dari Rasulullah kemudian sahabat dan telah mempraktikkannya secara turun temurun. Artinya, metode dan amalan yang digunakan oleh tarekat telah teruji selama berabad-abad dalam memperbaiki kejiwaan manusia. Bahkan hingga saat ini, keampuhan tarekat telah banyak dibuktikan, terutama oleh pesantren yang menampung santri dari berbagai macam latar belakang yang kelam.

\section{G. Referensi}

Aziz, Abdul. "Memahami Fenomena Sosial Melalui Studi Kasus" dalam Analisis Data Penelitian Kualitatif ed. Burhan Bungin. Jakarta : Raja Grafindo Persada, 2010.

Bruinessen, Martin Van. Tarekat Naqsyabandiyah di Indonesia. Bandung: Mizan, 1992.

Daradjat, Zakiah. Ilmu Jiwa Agama. Jakarta: Bulan Bintang, 1970.

Hawwā, Sa’ìd. Tarbiyatunā al-Rūhiyyah. Kairo: Maktabah al-Wahbah, 1992. 
Fathur Rohman

Madjid, Nurcholish. Islam Doktrin dan Peradaban: Sebuah Telaah Kritis tentang Masalah Keimanan, Kemanusiaan, dan Kemodernan. Jakarta: Paramadina, 2000.

Moleong, Lexy J. Metodologi Penelitian Kualitatif. Bandung: Remaja Rosdakarya, 2008.

Mufid, Fathul. "Spiritual teaching dalam Membentuk Karakter Siswa di SMK Islam Tsamratul Huda Tahunan Jepara". Edukasia: Jurnal Penelitian Pendidikan Islam 11, No.2 (Agustus 2016): 253-276, diakses pada 15 Agustus 2017

Najāty, M. Uthmān. Al-Qur'an dan Ilmu Jiwa terj. Ahmad Rofi Usmani. Bandung: Pustaka, 1985.

Salahudin, Marwan \& Binti Arkuni. "Amalan Tarekat Qadiriyah Wa Naqsyabandiyah Sebagai Proses Pendidikan Jiwa di Masjid Babul Muttaqin Desa Kradenan Jetis Ponorogo". Esoterik: Jurnal Akhlak dan Tasawuf 2, No.1 (2016).

Salim, Agus. Teori dan Paradigma Penelitian Sosial. Yogyakarta: Tiara Wacana, 2006.

Sugiyono. Metode Penelitian Kuantitatif, Kualitatif, dan $R \&$ D. Bandung : Alfabeta, 2009. . Metode Penelitian Pendidikan. Bandung: Alfabeta, 2005.

Sukmadinata, Nana Syaodih. Metode Penelitian Pendidikan. Bandung : Remaja Rosdakarya, 2009.

Wilda, Erham. Konseling Islami. Yogyakarta: Graha Ilmu, 2009.

Yunasril Ali, "Tasawuf”, dalam Ensiklopedi Tematis Dunia Islam, ed. Taufik Abdullah. Jakarta: Ichtiar Baru Van Houve, 2002.

Zahri, Mustafa. Kunci Memahami Ilmu Tasawuf. Surabaya: Bina Ilmu, 1995.

Zintāny (al), Abd al-Hamīd al-Ṣaid. Usūs al-Tarbiyah al-Islāmiyyah fi al-Sunnah alNabawiyyah. Tunis: Al-Dar al-'Arabiyah li al-Kitab, 1993.

Saenuri, Ahmad. Wawancara, Pati, 9 Desember 2016.

Thoyyib, KH. Fathur Rohman. Wawancara, Pati, 14 November 2017, 9 Desember 2016.

Zubair, Agus. Wawancara, Pati, 14 November 2017, 6 Desember 2016, 9 Desember 2016.

Jurnal Pendidikan Agama Islam (Journal of Islamic Education Studies)

Volume 5 Nomor 2 (2017)

ISSN(p) 2089-1946\& ISSN(e) 2527-4511

Hal. 180 - 180 